\title{
Online Health Consultation Services In Indonesia Law Perspective
}

\author{
Tiwuk Herawati ${ }^{1}$, Herwastoeti $^{2}$, M.Isrok ${ }^{3}$ \\ \{tiwukners@gmail.com ${ }^{1}$, herwastoeti@gmail.com², isrok@umm.ac.id ${ }^{3}$ \}
${ }^{1}$ Graduate Programs, Faculty of Law, Universitas Muhammadiyah Malang, Indonesia
${ }^{2}$ Department of Law, Universitas Muhammadiyah Malang, Indonesia
${ }^{3}$ Department of Law, Universitas Muhammadiyah Malang, Indonesia

\begin{abstract}
The rapid development of information technology in industrial revolution era 4.0 demands modern society to produce intellectual works that have brought plenty extraordinary changes among people's lives in almost all fields, both nationally and internationally. Rapid progress is happening in the global community, including the emergence of online health consultation services. This service needs legal assistance, thus the existence of the state as a law state can be maintained. Furthermore, the benefit of technological progress is maximally used by society and the country. This paper attempts to review the legal aspect of online health consultation services, since this sophisticated solution will create controversy without a legal entity. This research uses normative juridical approach. In normative legal research, literature review serves as a basic data which is classified as secondary data.
\end{abstract}

Keywords: health, consultation, legality, online

\section{Introduction}

Technological developments continue to evolve and change every second because of the highly needed information and dependence of technology innovations. Fast and dynamic information is important for industrial, trade and health sectors. Thus, electronic devices like smartphones that are now getting cheaper and easier to find in remote areas. These gadgets provide convenience in various aspects for its users. Technology has made it possible to sell products and services quickly and efficiently, while providing satisfaction for its users. In fact, nowadays technology has become part of human's personal life. Namely as a personal secretary, health, diet and sports trainer, investment manager and finance manager through mobile banking in a cashless society. In addition, through the latest application people are able to order a ride, food, massage and plane tickets, download the latest music from the most popular singer, play games, watch the latest movie and so on.[1]

Millennials as a technology savvy generation has been dominating Indonesian youth. Response speed from the younger generation in utilizing various advances and sophistication of the digital era must be utilized in the health sector. A survey conducted by Indonesian Internet Service Providers Association (APJII) in October 2016 reported that 132.7 million or $51.8 \%$ of Indonesia's population is connected to the internet. As the third largest smartphone user in the Asia Pacific, Indonesian internet penetration rate to children age 10-14 years old as well as employees in the private and health sectors is 100 percent. This means that technological advances provide opportunities for digital health as health programs in Indonesia.[2] 
Indonesian health care system is currently well developed. However, people still encounter some shortcomings. Namely, the doctor examination schedule is relatively short and has limited hours, moreover its queue is burdening. An on-house call doctor is also uneasy due to the doctor's tight schedule and the high costs. Based on these reasons, The existence of an online health consultation technology application will provide help for the patients.[3]

Currently patients are able to consult with the doctors about their health through various online applications and websites. These applications related to online transportation applications and would help patients to do an on-house check up, laboratory tests and drugs booking. This latest innovation was recognized as a industrial era 4.0 digital innovation, especially in terms of cost savings and efficiency. Some hospitals have implemented integrated electronic support systems, such as electronic medical records that can help doctors make better therapeutic decisions according to clinical electronic prescribing guidelines. However, lately there has been news on social media regarding false medication to a patient through online consulting services[4]. As a consequence, the online health consultation ethic is still debated in the medical viewpoint.

Consultation on personal and health problems can easily be done online. However, flexibility and openness in online platforms has caused a meaning shift in a "therapeutic contract" between doctors and patients. It is a legal relationship that involves the doctor and the patient called Inspaning Verbitennis therapeutic relationship. As a special legal agreement to conduct services, this relationship requires the doctors to do their work in maximum efforts[5]. Therapeutic agreements are defined as the legal medical service relationship between doctors and patients based on the doctor's medical skills competencies that are admitted by certain expertise and juridical experts. This therapeutic transaction is not only managing the drugs, but also gives promotive, diagnostic, preventive, and rehabilitative health [6]. Online health consultation through chat, telephone or video calls should be further considered based on the concepts of beneficence, autonomy, non-maleficence, and justice Online consulting service schemes are not complicated. Patients choose expert medical personnel in accordance with their complaints, then conduct health consultations through the available communication channels. Furthermore, patients will be billed according to medical personnel rates. Through this service, patients and doctors benefit from the cost, accessibility, convenience, increased privacy and communication, with certain conditions that must be agreed equally.[7]

The main problem is, the examination conducted online is not as thorough as face-to-face medical consultation. Doctors must examine a patient's physical including their body weight, height, blood pressure and heart rate through a stethoscope. Those examinations have ceased in online health consultation [8]. Minister of Health issued Regulation No. 46/2017 on the National e-Health Strategy and Regulation No.29 / 2019 on Telemedicine Services. However, technical and detailed aspects are not yet available in these regulations. Including the reliability of business models, service standards, workflows, patient safety, quality assurance, data protection, , supervision and guidance of e-Health applications.[9]

Based on the background written, there are two main problem in this paper about (1) how is online health consultation services legal provision based on telemedicine laws, (2) how is the doctor's accountability as an online health consultant based on the medical practice law and health law.

\section{Method}

The research method used is a normative legal research or library law research. In this method, literature review serves as a basic data which is classified as a secondary data. 


\section{Result and Discussion}

\subsection{Legal provisions for online health consultation services based on telemedicine laws.}

In Indonesia health services are still not optimally operated. Plenty of basic health facilities do not meet the standard criteria such as under level of health service quality and lack of facilities, medicines, medical devices and health workers. To increase the ability of life of the nation, basic health, science and technology policies and other sector policies need to be synergized. Telemedicine is one of the facilities that fulfil basic health needs. By using information and communication technologies, telemedicine overcomes geographical barriers, improves access to health services as well benefits rural communities in developing countries that lack access to health services.[10]

The World Health Organization has urged member countries to consider a long-term strategic plan for the development and implementation of e-Health services which including telemedicine. Besides, WHO also recommends them to establish institutions related to e-Health on national level and supported by the ministry of health as the executive [11]. Record of births and deaths as well as control of drug availability are also recommended.

Telemedicine policy has been regulated in Minister of Health Regulation No.20 of 2019 concerning the Implementation of Telemedicine Services Between Health Service Facilities. It is stated that telemedicine is a distance health service conducted by using information and communication technology by health professionals. Including information exchange on diagnosis, prevention of illness and injury, treatment, research and evaluation, and continuing education for health service providers to improve individual and community health. Telemedicine service conducted by health workers who have a license from the Health Service Facilities (HSF) administrator as the consultant and recipient of the consultation. Consultant HSF receive requests and provide telemedicine consulting services, namely hospitals owned by the central and regional government as well as private hospitals. Meanwhile, consultation recipients HSF are the one that send telemedicine consultation requests like hospitals, firstlevel health facilities, and other health facilities.[12]

The types of health facilities refer to article 4 paragraph (1) Government Regulation Number 47 Year 2016 concerning Health Service Facilities. Those are health workers' independent practice, clinics, optics, community health centers, pharmacies, hospitals, health laboratories, blood transfusion units, medical service facilities for traditional health and legal purposes service facilities. Telemedicine services include tele-radiology, teleelectrocardiogram, tele-ultrasonography, clinical teleconsultation and other telemedicine consulting services related to science and technology development.[13]

Online health consultation categorized as clinical teleconsultation, a distance clinical consultation services to help diagnose, and / or provide advice, implementation and consideration. Indonesian Health Ministry mention four telemedicine services provided in their official website Telemedicine Indonesia (Temenin) namely radiology, ultrasound, electrocardiography and consultation. Teleconsultation on this website aims to unite patients with expert doctors through an online consultation to find out the patient's condition and make treatment recommendations.

Digital platform that provides online health consultation and facilitates health service search is currently popular in Indonesia. Every e-health business platform should be listed by the Ministry of Communication and Information as an electronic system provider. Referring to the Minister of Health Regulation 20/2019 article 12 paragraph 2 and 3, telemedicine application is only provided by the Ministry of Health. Thus, other independent developed applications, both e-business and telemedicine practitioners must be registered by both ministries.

Based on Law Number 19 of 2016 concerning Information and Electronic Transactions, the electronic system organizer is defined as every person, business entity, state operator, and community that provides, manages, and or operates electronic systems to the users 
independently or jointly for their own needs and or other party's needs [14]. Minister of Health Regulation No. 46 of 2017 Regarding the National E-Health Strategy explains that e-health is utilization of information and communication technology for health services and information. Especially to improve health service quality as well as an effective and efficient work process[15]. It is important to note the difference of liaison platforms, service providers and telemedicine providers.

Both consultant HSF and consultation recipient HSF must be registered by the Minister of Health through the Directorate General of Health Services. Meanwhile, online health consultation platforms with its doctors are not the part of both HSF, so that their service is not categorized as telemedicine. Online applications and websites run as platforms that offer various health services are not telemedicine between HSF, as mentioned by Minister of Health Regulation 20/2019. Thus, the government must immediately create regulations regarding online health consultation services, so that they can have legal implications.

\subsection{Accountability of doctors who conduct online health consultations based on the Medical Practice Act and the Health Act.}

Article 1 paragraph 7 of Law No. 36 of 2009 concerning Health defines health facilities as tools and or places used to carry out health services, both preventive, curative, promotive and rehabilitative conducted by the community, regional governments and the central government. [16]. Health is a state of well-being of the body, soul and social that enables everyone to live productive socially and economically. Health care by preventing health problems requires examination, treatment and care that can be done online. Online health consultation service platforms and applications that provide consultation and health protection service are demanded by the community.[17]

Government Regulation No. 47 of 2916 Article 4 paragraph 1 concerning Health Service Facilities mentioned clinic as one of the health service facilities for the community. According to Minister of Health Regulation No. 9 of 2014 article 1 paragraph 1, clinics provide individual, basic and specialist medical services like in the hospital. Health workers provide health services to patients. Then the doctor conducts a physical examination by looking (inspection), palpating (palpating), knocking (percussion), listening (auscultation) and smelling (smelling). Furthermore, the doctor conducts supporting examinations, such as laboratory and radiological examinations if necessary. Finally the doctor diagnoses the patient's illness with his medical science as mentioned in the Medical Standard Operating Procedure and prescribes medicine for the patient [18]. In online health consultation, patients consult with a doctor without going through a physical examination and supporting examination. However, doctors can still provide medication and prescription recommendations without meeting the patients.

By conducting an online health consultation, patients feel comfortable because they do not need to leave the house, examination is also more affordable and efficient. Despite its advantages, various aspects of online health consultation need to be explored further, especially in terms of medical records [19]. Law Number 29 of 2004 concerning Medical Practices article 46 paragraph 1 to 3 states that every doctor or dentist holding medical service is obliged to write down medical records as soon as the examinations are done. Officer's names, times and signatures who provide services or actions must also be recorded [20]. In line with article 57 paragraph 1 of Law no. 36 of 2009 concerning health, every patient has the privacy rights on their health condition mentioned to the health service providers. Regulation on protecting the patient's privacy rights over electronic medical records in the health care facilities also needs to be regulated to limit access for unauthorized parties. Confidentiality guarantee for patient medical records should be written on paper so that it has legal implications if abuse occurs.[21]

Compared to the medical practice standard at conventional clinics, the patient's privacy rights regulation is more obvious. Unfortunately, there is a high possibility of patient misdiagnosis through online health consultation. Thus, the government must immediately create regulation for online health consulting services to ensure user data security. The rules regarding drug delivery through online health applications also need to be explored. On one 
hand, society needs technological advancement in medical services, on the other hand governments have to update the regulation on it. So that, medical practice, the doctors and patients obtain legal protection.

Article 23 paragraph 3 of Law Number 36 Year 2009 concerning Health which regulates the delivery of health services requires health workers to have permission from the government. Article 36 of Law Number 29 Year 2004 concerning Medical Practices regulates that dentists and doctors who practice medicine in Indonesia are required to have a practice permit. Based on both regulations, it is clear that as a medical practitioner, doctors are able to perform medical practice after obtaining a practice permit from the district / city health office.

Doctor and patient relationship also mentioned in Law No. 29 of 2004 concerning Medical Practice. Medical practice is implemented based on the agreement of health relations, treatment of diseases and health recovery, health promotion and disease prevention. The agreement mentioned must be made by dentists and doctors for medical profession devotion. Healing and recovery is carried out to the fullest in accordance with patient medical needs, standard operating procedures, service standards and professional.[21]

Applicable location of practice license regulated in article 37 paragraph 2 and paragraph 3 of Law Number 29 Year 2004 concerning Medical Practices. In paragraph 1, a doctor's or dental practice permit is only granted for at most three places. Paragraph 2 stipulates that a practice permit is only valid for one practice place. According to article 38 Paragraph $1 \mathrm{~b}$, the doctor or dentist must have a place of practice. To sum up, medical practice providers and health service providers must have a practice location. So practice location of online health consultation doctors are still questionable legally and ethically. It is hoped that the government will soon create regulation about online health consultation services. [20]

Health Act article 59 also regulates traditional health services that are defined as treatment through manner and medicine which refers to hereditary experience and skills empirically that can be justified and applied in accordance with prevailing society norms.

The World Health Organization defines traditional health service as a combination of knowledge, practice and skills based on beliefs, theories, and experiences from certain cultures, both those that can be explained or not, which are used in health care and diagnosis, prevention, improvement or treatment of physical and mental illness. Traditional health service regulated both in Health Act, Government Regulation No. 103/2014 concerning Traditional Health Services and Minister of Health Regulations that divided into several types, namely empirical, integration and complementary traditional health services, spa health, efforts to develop traditional health through independent usage of family herbal medicine (Asman TOGA) and acupressure [21]. To sum up, online health consulting services require national regulation in order to provide legal certainty like traditional health services. So that technological development demands in the health sector can be answered if experiencing legal problems.[20]

\section{Conclusion}

As a medical service provider, doctors have authority to practice medicine with a permit granted by the government, because the state is responsible for regulating and fostering medicine practice in Indonesia. Medical practice through online consulting service is influenced by many factors, namely social, economic, political, cultural, security and defense as well as technology and science. Thus, those factors potentially change medical practice orientation in terms of values and consideration and later may affect the health development process. Moreover, specific license regulations made by the government and the provisions regarding its accreditation are not yet available. Thus, national standards and guidelines for online health consultation services need to be established, so that responsible, safe, qualified, equitable and non-discriminatory health services can be created. This is a shared responsibility between the government, health practitioners and the community. 
Online health consultation services usage has increased annually because many health services in the world today have adopted it. The effectiveness of promotive and preventive health services has been proven by many studies and it helps to promote health. Although many benefits are offered from online health consultations, the usage should be considered wisely. Because technology may strengthen the mechanistic paradigms and instrumental approaches to the human body. Unfortunately the law is always left behind. It is time for the government to create regulations on online health consultation services. So, as a part of technological developments in medical practice, patient data security is guaranteed and legal implications are made.

\section{Acknowledgments}

The author wishes to thank the head of Muhammadiyah Malang University and Head of Faculty of Law for providing a facility to join international conference in ICILS 2020 UNNES

\section{References}

[1] R. R. Tjandrawinata and D. Medica, "Industri 4 . 0 : Revolusi Industri Abad Ini dan Pengaruhnya Pada Bidang Kesehatan dan Bioteknologi," no. February, 2016.

[2] A. P. Sunjaya, "Potensi , Aplikasi dan Perkembangan Digital Health di Indonesia," no. April, pp. 167-169, 2019.

[3] G. Santoso, H. Musthofa, P. Studi, and T. Elektro, "Aplikasi Mobile Doctor Untuk Meningkatkan layanan Medis,” vol. 5, no. 1, pp. 451-457, 2011.

[4] Kominfo, "Layanan Kesehatan dan Kemajuan Teknologi Digital." Kumparan.com, 2019.

[5] Triyanta, "Informed Consent: Studi Tentang Perlindungan Hukum Bagi Pasien Pada Tindakan Operasi Di RSUD dr. Soeratno Gemolong Sragen," 2018.

[6] D. A. Purwadi, "Sidang Pemeriksaan Polemik Bayi Tabung Klinik Ferina," Surabayapagi.com, Surabaya, 2017.

[7] R. T. Budiyanti, "Hubungan Dokter- Pasien Melalui Media Sosial Ditinjau Dari Prinsip Dasar Bioetika," vol. 37, p. 2014, 2014.

[8] A. P. Singh, H. S. Joshi, A. Singh, M. Agarwal, and P. Kaur, "Online medical consultation : a review Online medical consultation : a review," no. March, 2018.

[9] B. H. Sianipar, "Kebijakan Pengembangan Tele-Medisin Di Indonesia," pp. 42-62.

[10] Peraturan Menteri Kesehatan Republik Indonesia Nomor 20 tahun 2019 tentang Penyelenggaraan Pelayanan Telemedicine Antar Fasilitas Pelayanan Kesehatan. 2019.

[11] Peraturan Pemerintah Nomor 47 Tahun 2016 Tentang Fasilitas Pelayanan Kesehatan. 2016.

[12] Undang Undang Nomor 19 Tahun 2016 Tentang Perubahan Atas Undang- Undang Nomor 11 tahun 2008 Tentang Informasi dan Transaksi Elektronik. 2016.

[13] Peraturan Menteri Kesehatan Nomor 46 Tahun 2017 Tentang Strategi E-Kesehatan Nasional. 2017.

[14] Undang Undang Nomor 36 tahun 2009 Tentang Kesehatan. 2009.

[15] E. Nurfarida, R. Widyastuti, and A. Hadi, "Aplikasi Mobile untuk Konsultasi dan Booking Praktek Dokter,” vol. 07, no. 01, pp. 1-7, 2015.

[16] W. Saputri, “Tanggung Jawab Dokter Terhadap Kesalahan Diagnosis Dalam Layanan Klinik Kesehatan Berbasis Website (Klinik Online)," 2019.

[17] P. Prawiroharjo, J. Sundoro, J. Hartanto, G. F. Hatta, and A. Sulaiman, "Tinjauan Etik Layanan Konsultasi Daring dan Kunjungan Rumah Berbasis Aplikasi,” vol. 3, no. 2, pp. 37-44, 2019.

[18] Undang- Undang Republik Indonesia Nomor 29 Tahun 2004 Tentang Praktik Kedokteran. 2004.

[19] A. Anwar, "Aspek Hukum Pengunaan Telemedicine." 2013.

[20] M. A. I. Arif, "The Legal Review Of Online Based Medical Services," 2018. 
[21] Y. Situmorang, "Pelayanan Kesehatan Tradisional Integrasi di Indonesia: Tantangan dan Kemajuan Terkini," 2018. 